\title{
Effective Methods in Learning Arabic Language as a Foreign Language
}

\author{
Assoc. Prof. Dr. Rosni bin Samah \\ Fariza Puteh-Behak \\ Noor Saazai Mat Saad \\ Suraini Mohd Ali \\ Ramiaida Darmi \\ Haliza Harun
}

Faculty of Major Languages, Universiti Sains Islam Malaysia; rosni@usim.edu.my

Doi:10.5901/mjss.2016.v7n3p349

\section{Abstract}

Students who learn Arabic as a foreign language in a foreign country usually face difficulties to achieve proficiency in the language. This is primarily because of the lack of Arabic language resources. However, this situation does not hinder the emergence of a group of outstanding students who achieve fluency in Arabic by using their own methods. This study investigated the methods used by these students to be used as a guideline for other students. To collect the data, a set of questionnaire was developed from the Imitation Strategy Instrument introduced by Rosni Samah (2014). The questionnaires were distributed to 50 outstanding final year students from the Arabic language department, Faculty of Major Languages, Islamic Science University of Malaysia. The results showed that effective strategies for learning Arabic language as a foreign language were gathering, enhancing and applying. The targets are new vocabulary and sentence. The tools to perform the strategies were Arabic materials and language activities. This study recommends that in learning Arabic language as a foreign language, the three methods mentioned above should be applied. The Arabic materials should be provided and language activities should be organized. The effective methods used by outstanding students should be used as a guideline for other students to be more proficient in Arabic Language.

Keywords: methods, foreign language, Arabic language, learning, Malaysia.

\section{Introduction}

The teaching and learning of Arabic language in Malaysia at this present moment is facing an enormous challenges. The main problem is the pedagogical approach usually employed by most Arabic language teacher who use the traditional method in teaching. According to the research conducted by Azhar et al. (2008); Amarulzaman et al. (2002) and Abdul Halim (2005) some Arabic language teachers prefer to us a teaching method which concentrates more to the teacher and has less students' involvement. M. Fadli and M. Syukki Othman (2012) stated that some teachers rarely contribute to the student's achievement.

On the other hand, the problem originates from the students themselves. They are weak in their Arabic proficiency and also use the traditional method in learning Arabic. This is witnessed by studies by Tarmizi (1997); Anida (2003); Naimah \& Aini (2005); Kamarulzaman \& Nik Rahimi (2005); Nasimah (2006); Ab. Halim (2007) (2009) Zarima et al. (2008); Mat Taib (2008); Kamarul Syukri (2009); Zawawi Ismail et al. (2011); Nur Amirah (2011) and Rosni Samah (2012). M. Hanan (2011) explained that most students prefer to just sit and listen to the teacher in learning the Arabic language. Moreover, they feel afraid to speak and be involve in activities in the Arabic Language class. As a result, Syakirah (2004) found that students face difficulties in understanding the Arabic Language subject.

Rosni b. Samah (2013) exspressed that the weakness actually comes from the students' personality or passive attitudes. This attitude can be seen through the actions of the students in the class. It occurs because they rarely apply proper learning strategies and coupled with the lack of awareness. Thisstatement is supported by Anida (2003); Nurazan (2004); Kamarul Syukri (2009); Sueraya et al. (2010); Mastura \& Kaseh (2012) and Rosni Samah (2014).

Conversely, there are groups of students who showed excellence in their Arabic Language experience which is the 
medium of instruction in their studies. These are the final year students who have achieved outstanding results in their studies. In their pursuit of becoming outstanding students in Arabic studies, they have used an effective method in learning Arabic which has been used from their first year until their final year of studies. This effective method can be used as a guideline for other students to emulate. Based on this fact, this study tried to investigate their methods in learning Arabic language and expose them to others.

\section{Methodology}

\subsection{The participants}

The participants were selected from final year students from the Arabic language department from the Faculty of Major Languages, Islamic Science University of Malaysia for session 2014/2015. They are 50 outstanding students (28\% males and $72 \%$ females) who achieve the cumulative grade point average (CGPA) between 3.0 to 4.0 . Among them $26 \%$ of the students have the CGPA of 3.5 and above while $74 \%$ of them are between the CGPA of 3.0 until 3.4. According to the result obtained from the questioners, they are $98 \%$ students have high motivation in learning Arabic language and 100\% students have their self (internal motivation) motivated them.

\subsection{Instruments}

To gather the information, a set of questionnaire was distributed to each of them. The questionnaire was developed based on the Imitation Strategy Instrument introduced by Rosni Samah (2014); which was based on the opinions of Ibn Khaldun (1987). This instrument was chosen based on its success and it has been proven by the other researchers and previous studies. The excellent students from the Faculty of Major Languages, Islamic Science University of Malaysia for session 2013/2014 proved their success in Arabic language by using this strategy. The instrument highlights three main strategies that are gathering, enhancing and applying. There are three sub strategies components; target, activities and materials. The three main strategies above have been changed into three methods for learning Arabic language. Each method has its own steps to be implemented. It has a 73-item instrument that required students to report the frequency on the usage of language learning methods.

\subsection{Data analysis}

To evaluate students' performance, this questionnaire has 5 scales from 1 until 5 . The indicators are as mentioned by Oxford (1990) 1 = never or almost never true of me, 2 = usually not true of me, 3= somewhat true of me, 4 = usually true of me and $5=$ always or almost true of me. Students were asked to choose only one of the five options pertaining to their performance in learning Arabic language. To analyze the data, the data obtained from the checklist were codified and entered into the Statistical Package for Social Sciences (SPSS, version 16). Descriptive statistics were used to determine the mean of the statements in the checklist. A range of 3.5 to 5 on the item is thought to reflect the high use of that method.

\section{Results and Discussions}

The results showed that students had two main instruments in learning Arabic language that are Arabic materials and language activities. The Arabic materials were text books, dictionaries, magazines, newspapers, advertisements, internet, cartoon materials, radio programs, TV programs, recorded materials, friends, teachers, and Arabic speakers. The language activities are reading, listening, interaction, and writing activities. The success of using those materials has been proven by Nurhamimi Zainul Abidin \& Muhamad Fiham Muhammad Ghalib (2012). The effectiveness of language activities has been proven by Madkur \& Iman (2006); Rim Adil at-Tarik (2011); Mahmud Mohamad Ali \&Nursabila Muhamad (2011); Tinggari (2011); Daud (2011); and Yasir \& Rahmah (2011) who stressed that language activities played the most important role in improving students' proficiency.

For these students, their targets were usually new vocabularies and sentences. To be successful in the acquisition of new vocabularies and sentences they have planned a way of learning method such as gathering, enhancing and applying. In implementing their way of learning, they had named the steps for each method as mentioned above. 


\section{Gathering Method}

The gathering method had four steps namely searching, recording, asking and referring. The results are as follows:

Table 1: Results for gathering method.

\begin{tabular}{|c|c|c|c|c|c|}
\hline No. & Steps & Targets & Activities & Materials & Means \\
\hline \multirow[t]{2}{*}{1} & \multirow[t]{2}{*}{ searching } & \multirow[t]{5}{*}{$\begin{array}{l}\text { New } \\
\text { vocabulary and } \\
\text { sentence }\end{array}$} & reading, listening & $\begin{array}{l}\text { text books, dictionaries, magazines, newspapers, } \\
\text { advertisements, internet, cartoon materials, radio programs, } \\
\text { TV programs, recorded materials }\end{array}$ & 3.8200 \\
\hline & & & interaction & friends, teachers, and Arabic speakers & 3.5284 \\
\hline 2 & recording & & $\begin{array}{l}\text { reading, listening and } \\
\text { interaction }\end{array}$ & $\begin{array}{l}\text { text books, dictionaries, magazines, newspapers, } \\
\text { advertisements, internet, cartoon materials, radio programs, } \\
\text { TV programs, recorded materials, friends, teachers, and } \\
\text { Arabic speakers }\end{array}$ & 3.5267 \\
\hline 3 & asking & & $\begin{array}{l}\text { reading, listening, } \\
\text { writing and interaction }\end{array}$ & friends, teachers, and Arabic speakers & 3.6283 \\
\hline 4 & referring & & \begin{tabular}{|l|} 
reading, listening, \\
writing and interaction
\end{tabular} & Dictionaries, friends, teachers, and Arabic speakers & 3.8850 \\
\hline
\end{tabular}

Using Arabic material was considered as a tool to acquire new vocabularies and sentences. The outstanding students used that Arabic materials to gather and acquire the language. The studies conducted by Nur Wahdah (2011); Nur Hashimah (2012); Khairul Sakinah (2012) and Siti Asiah (2013) supported the effectiveness of using this method.

In gathering new vocabularies and sentences, they applied searching, recording, asking and referring methods to acquire new vocabularies and sentences. The effectiveness of using those steps was witnessed by Wan Nur Zadilah, (2012); Idham Muslim, (2013); Muhamad Thaqif, (2013); Wahdah Asma' (2011); Rohana Nawi (2012) and Ibrahim Adisola (2013).

To perform the four steps in gathering new vocabularies and sentences, the outstanding students used the language activities as a medium in learning Arabic language. The language activities provided opportunities for reading, listening, writing and speaking or interaction. The studies conducted by Nur Farhana (2012); Nur Khadijah Abu Bakar (2012); Mohamad Faris (2012); Ibrahim Adisola (2013) and Siti Aishah (2013) supported the effectiveness of this method in gathering new vocabularies and sentences.

\section{Enhancing Method}

After gathering the new vocabularies and sentences, the excellent students used a second method that was applying an enhancing method via eight steps such as memorizing, imitating, interacting, recording, repeating, correcting the errors, translating, and building the sentences. They implemented them in the language activities such as reading, listening, interaction or communication and writing by using the Arabic materials as a reference as well as in the first method. Researchers such as Ain Nabihah Ahmad (2011); Ismail (2011); Nadwah Ibrahim (2011); Yayan Nurbayan (2011); Khadijah Salma (2011); Nur Khadijah (2012); M. Fauzi (2012); Rohaizaf (2013); Rosni et al. (2013); Amizan (2013); Shafirol (2013); NurFazila Ismail (2013); Harnani Abu Bakar (2013); and Azlan (2013) witnessed the effectiveness of using the above steps. The results are as follows:

Table 2: Results for enhancing method.

\begin{tabular}{|c|l|c|}
\hline No. & Steps & Means \\
\hline 1 & Students interact by using vocabulary and sentence in reading, listening, interaction and writing activities & 3.9500 \\
\hline 2 & Students translate vocabulary and sentence in reading, listening, interaction and writing activities & 3.7600 \\
\hline 3 & Students correct the errors of vocabulary and sentence in reading, listening, interaction and writing activities & 3.7367 \\
\hline 4 & Students repeat vocabulary and sentence in reading, listening, interaction and writing activities & 3.7067 \\
\hline 5 & Students build the sentences in reading, listening, interaction and writing activities & 3.7017 \\
\hline 6 & Students memorize vocabulary and sentence in reading, listening, interaction and writing activities & 3.6900 \\
\hline 7 & Students record vocabulary and sentence in reading, listening, interaction and writing activities & 3.6833 \\
\hline 8 & Students imitate vocabulary and sentence in reading, listening, interaction and writing activities & 3.6600 \\
\hline
\end{tabular}


Those results showed that interacting has the highest score which shows that students always use it in learning Arabic language. The effectiveness of interaction was supported by Shahidah (2012); Nur Khadijah (2012), and Nur Farhana (2012).

There were four steps that have the means of 3.7 and above. They were translation, correcting the errors of vocabulary and sentence, repeating and building the sentences. This result shows that students always use them in enhancing their new vocabularies and sentences. The effectiveness of translation in enhancing the language was supported by researchers such as Muhamad Ridwan (2013) and Nur Hanim (2013). The effectiveness of correcting the errors of the vocabularies and sentences in enhancing the language was also witnessed by Azlan bin Saif Baharum (2013). Nur Khadijah (2012), Rohaizaf (2013) Mohd Fauzi Abdul Hamid (2012), Shaferol (2013), Rosni Samah et al. (2013) and Amizan Hilmi (2013) who all supported that using repetition help students to improve their language proficiency. Mohd Fauzi Abdul Hamid (2012), Haslina (2013), Muhamad Thaqif (2013) and Shaferol (2013) stressed that the effectiveness of building the sentences in various activities can improve language proficiency.

The remaining three steps achieved the range of means of 3.6, indicating students used them quite regularly. They were memorizing, recording and imitating the new vocabularies and sentences. Nur Khadijah (2012); Haslina (2013); and Siti Aishah (2013) indicated the effectivenes of memorizing new vocabularies and sentences in various activities to enhance language proficiency. Wan Nur Zadilah (2012), Idham Muslim (2013) and Muhamad Thaqif (2013) stated that students always record the new vocabularies and sentences in various activities to enhance their language proficiency. Mohd Fauzi Abdul Hamid (2012), Shaferol (2013), Rosni Samah et al. (2013) and Amizan Hilmi (2013) supported the effectivenes of imitating to enhace the language skills.

\section{Applying Method}

In the process of acquiring the language proficiency, students used language activities as a tool to practice the language in the real language situation. Muhamad Faris (2012), Ruzila Zakaria (2013), Muhamad Farid (2013), Muhamad Thaqif (2013) and Ibrahim Adisola (2013) suggested that the language activities should be organized to give students the opportunities in using newly acquired vocabularies and sentences. Among them are language camps, language theater, language competition, language debate, language explorace, language writing competition, language movie and language public speaking.

The results showed that students used the applying method which has nine steps namely communicating, interacting, presenting, acting, doing role play, translating, writing, listening and reading in learning Arabic language. For the success of this method, students have the Arabic environments to use the language as suggested by Ibnu Khaldun (1987). The results for the nine steps are as follows:

Table 3: Results for applying method.

\begin{tabular}{|c|l|c|c|c|}
\hline No. & Steps & Targets & Activities & Means \\
\hline 1 & interacting & using vocabulary and sentence acquired & In language activities & 4.0200 \\
\hline 2 & Communicating & & & 3.9800 \\
\hline 3 & listening to & & 3.9800 \\
\hline 4 & writing & & 3.9000 \\
\hline 5 & reading & & 3.8400 \\
\hline 6 & translating & & 3.8200 \\
\hline 7 & acting & & 3.8000 \\
\hline 8 & doing role play & & 3.6400 \\
\hline 9 & presenting & & 3.5918 \\
\hline
\end{tabular}

The results above show that the interaction by using acquired vocabularies and sentences in language activities has the highest score of 4.0200. It indicated that students always use it to apply their acquired language. It is followed by communicating, listening to, writing, reading, translating and acting. The lower steps were doing role play and presenting. Those results revealed that students always use those nine steps to applying their acquired language in language activities. The effectiveness of using those nine steps in learning Arabic language has been proven by Nur Syaifura (2011); Ismail (2011); Ghazali Yusri et al. (2012); Mashurah (2013); Nur Afifah (2013); Asmuni (2013); Nasimah Mukti (2013); Siti Nur Huda (2013); Nur Azrin Muhamad (2013); Nur Najwa Jamaluddin (2013); Nur Aisar Nurudin (2013); Siti Asiah Muhamad (2013) and M. Abdul Latif (2013). 


\section{Conclusion}

Apart from the above results, it seems that the outstanding students have their own methods in learning Arabic language as a foreign language. They build their own situations in acquiring the new language. Moreover, they possess their own methods and steps to be applied in language activities that later will be practiced in the real language situation. Additionally, they also provide the Arabic materials as a reference. The effectiveness of their methods are also supported by other researchers. The overall results of using the above methods are as follows:

Table 4: Results for overall methods.

\begin{tabular}{|c|l|c|}
\hline No. & Methods & means \\
\hline 1 & Gathering & 3.6361 \\
\hline 2 & Enhancing & 3.7358 \\
\hline 3 & Applying & 3.8425 \\
\hline 4 & Overall using & 3.7382 \\
\hline
\end{tabular}

From the sequins above, it shows that students use applying method more that enhancing and gathering methods. For that reason, they have high level of proficiency even though they learn Arabic in a foreign country which is situated so far from Arabic countries and Arabic culture. Hence, their methods can serve as a guideline for other students.

\section{References}

Ab. Halim Mohamad. (2007). Masalah Komunikasi Bahasa Arab di Kalangan Pelajar Bacelor Bahasa Arab di IPTA Malaysia. Prosiding Seminar Penyelidikan Dalam Pengajian Islam Ke-4.

Ab. Halim Mohammad. (2009). Tahap Komunikasi dalam Bahasa Arab dalam Kalangan Pelajar Sarjana Muda Bahasa Arab di IPTA Malaysia. Journal of Islamic and Arabic Education 1(1).

Abdul Halim Mohamad. (2005). Kelayakan Guru Bahasa Arab dalam Pengajaran Bahasa Arab: Satu Kajian Kes. Prosiding Wacana Pendidikan Islam Siri 4.

Ain Nabihah Ahmam. (2011). Tayin Akhta' Lughawiyah fi Jumlah Arabiyah lada Talamiz al-Sanah al-Rabiah bi al-Madaris al-Thanawiyah al-Diniyah bi WilayahSelangor. BA thesis. Faculty of Major Languages. Nilai: Islamic Science University of Malaysia.

Amizan Hilmi. (2013). Turuq Tadrib Maharah Kalam lada Mutanadzirin bil Madaris Thanawiah fi Malizia. MA thesis. Nilai: Islamic Science University of Malaysia.

Anida Abd. Rahim. (2003). Strategi Pembelajaran Bahasa Arab di Kalangan Pelajar Melayu, MA thesis, Universiti Malaya, K. Lumpur.

Asmuni Zumrah. (2012). Khauf fi Takdim bi Lughah Arabiah: Talabah Thanah Thaniah Barnamij Lughah Arabiah FPBU. BA thesis. Faculty of Major Languages. Nilai: Islamic Science University of Malaysia.

Azhar Hj. Ahmad, Hosen Marip dan Morsalin Pawi. (2008). Kajian Tinjauan Pelaksanaan Pengajaran dan Pembelajaran Bahasa Arab di Sekolah Menengah di Negeri Sarawak. Prosiding Wacana Pengajian Islam, Siri 6.

Azlan bin Saif Baharum. (2013). Akhta' Lighawiyah Syai'ah fi Ta'bir Kitabi Wadzifi lada Talabah Mutkhassisin fi Lughah Arabiah fi Jamiaat Hukumiah Maliziah. Ph.D thesis. Nilai: Islamic Science University of Malaysia.

Daud Abdul Kadir. (2011). Ittijahat Jadidah fi Mualajah Mushkilat al-Kalam lada Mutaallimi al-Lughat al-Ajnabiyah. Prosiding Language \& Education Conference 2011.

Ghazali Yusri, Nik Mohd Rahimi, Parilah M. Shah, Wan Haslina Wah dan Muhammad Sabri Sahrir. (2012). Penggunaan Bahasa Arab Lisan dan Hubungannya dengan Strategi Pengurusan Sumber.GEMA Online ${ }^{\text {TM }}$ Journal of Language Studies, Volume 12(2), May 505-520.

Harnani Abu Bakar. (2013). Istiratijiah Tanmiah Tharwiyyah Lughawiyyah lada Talabah Thasan Rabiah Kuliah Dirasaat Lughah Raisah bi USIM. BA thesis. Faculty of Major Languages. Nilai: Islamic Science University of Malaysia.

Haslina Abdul Ghani. (2013). Asar Mumarathah Lughah Arabiyyah fi Takwiyyah Maharah Muhadathah lada Tolabah Sanah Rabiah Kulliyyah Lughaat Raisah fi bi Jamiah Ulum Islamiyyah Maliziyyah. BA thesis. Faculty of Major Languages. Nilai: Islamic Science University of Malaysia.

Ibnu Khaldun. (1987). Muqaddimah Ibnu Khaldun. Beirut: Dar Qalam.

Ibrahim Adisola. (2013). Mushilaat allati Yuwajihuha Tolabah fi Thahathdus bi Lughah Arabiyyah. BA thesis. Faculty of Major Languages. Nilai: Islamic Science University of Malaysia.

Idham Muslim. (2013). Ma'rifah Mustawa Maharah Kitabah lada Tolabah Sanah Ula bi Kulliyyah Lughaat Raisah bi Jamiah Ulum Islamiyyah Maliziyyah. BA thesis. Faculty of Major Languages. Nilai: Islamic Science University of Malaysia.

Ismail, Hasanain Ahmad. (2011). Al-Lughah al-Arabiyah li al-Natiqin bi Ghayriha Bayna Tacallum wa Takallum fi al-Jamiah al-Islamiyah al-Alamiyah. Prosiding Seminar Antarabangsa Bahasa CELPAD, UIA.

Kamarul Shukri Mat Teh. (2009). Penggunaan Strategi Pembelajaran Bahasa Arab dalam kalangan pelajar sekolah menengah agama. Tesis PhD. Universiti Kebangsaan Malaysia. 
Kamarulzaman Abdul Ghani dan Nik Mohamad Rahimi. (2005). Menilai Kebolehbacaan Buku Teks Bahasa Arab Tinggi: Ke Arah Meningkatkan Kemahiran Membaca Pelajar. Prosiding Wacana Pendidikan Islam, Siri 4.

Kamarulzaman Abdul Ghani, Khadijah Abdul Razak dan Mohd Amin Embi. (2002). Tahap Profesionalisme Guru Pendidikan Islam dan Bahasa Arab di Sekolah Menengah Agama Negeri (SMAN) di Kelantan. Prosiding Seminar Kebangsaan Profesion Perguruan.

Khadijah Salma Ahmad Ali. (2011). Anshitah Musaidah fi Taallum Lughah Arabiyah lada Talabah al-Sanah al-Thalithah. BA thesis. Faculty of Major Languages. Nilai: Islamic Science University of Malaysia.

Khairul Sakinah Ibrahim. (2012). Mustawa Idrak Ahammiyah Istima' fi Ta'alum Lughah Arabiyyah lada Tolabah Sanah Ula bi Takhasus Dakwah Islamiyyah bi Kulliyyah Qiadah wa Idarah bi Jamiah Ulum Islamiyyah Maliziyyah. BA thesis. Faculty of Major Languages. Nilai: Islamic Science University of Malaysia.

Madkur, Ali Ahmad dan Iman Ahmad. (2006). Talim Lughah Arabiyah li Ghayr al-Natiqin Biha: Nazariyah wa Tatbiq. Al-Qahirah: Dar alFikr.

Mahmud Mohamad Ali dan Nur Sabila Muhamad Ali. (2011). Dawr Nashat Munazarah fi Tanmiyah Maharah Lughah Arabiyah. Prosiding International Language Conference 2011. Universiti Islam Antarabangsa Malaysia.

Mashurah Mohamad Rawi. (2013). Ta'sir Daurah Tadribiyyah fi Raf'l Maharah Kitabah lada Tolabah Sanah Thalithah wa Khamisah bi Ma'had Tahfiz Jendalah. B A thesis, Faculty of Major Languages. Nilai: Islamic Science University of Malaysia.

Mastura \& Kaseh. 2012. Penggunaan Strategi Pembelajaran Kemahiran Bertutur Bahasa Arab: Kajian Di Pusat Asasi Uiam, Persidangan Kebangsaan Pengajaran Dan Pembelajaran Bahasa Arab 2012 (PKEBAR'12). Banggi: UKM.

Mat Taib Pa. (2008). Isu-isu pengajaran bahasa dan kesusasteraan Arab di institut pengajian tinggi. Prosiding Seminar Pengajaran Bahasa dan Kesusasteraan Arab di Institut Pengajian Tinggi Malaysia. Jabatan Bahasa Arab dan Tamadun Islam, FPI UKM.

Mohd Fadzli Ismail \& Mohd Sukki Othman. 2012. Faktor Yang Mempengaruhi Pencapaian Pelajar Dalam Pengajaran \& Pembelajaran Bahasa Arab: Satu Tinjauan Di Smap Kajang. Banggi: UKM.

Fauzi Abdul Hamid. (2012). Istiratijiyah al-Muhakat wa Turuquha fi Taclim al-Insya' wa Tacallumihi ala Mustawa al-Shahadah al-Diniyah al-Maliziyah (STAM). MA thesis, Faculty of Major Languages. Nilai: Islamic Science University of Malaysia.

Muhamad Abdul Latif b. Nasir. (2013). Istikhdam Lughah Arabiah fi Hayat Yaumiah lada Talabah Kuliah Sanah Thaniah bi Kuliah Dirasaat Raisah Takhasus Lughah Arabiah wa Ittisalaat Namuzajan. BA thesis. Faculty of Major Languages. Nilai: Islamic Science University of Malaysia.

Muhamad Hanan. (2011). Asbab Khawf lada Talabah Jamiah Malaya fi Kulliyah Islamiyah fi Muhadathah. BA thesis. Faculty of Major Languages. Nilai: Islamic Science University of Malaysia.

Muhamad Ridwan. (2013). Maharah Tarjamah Majallah mi Lughah Arabiyyah ila Jumlah Arabiyyah lada Tolabah Sanah Thaniah Kulliyyah Lughaat Raisah bi Jamiah Ulum Islamiyyah Maliziyyah. BA thesis. Faculty of Major Languages. Nilai: Islamic Science University of Malaysia.

Muhamad Thaqif. (2013). Barnamij Takwiyah Lughah Arabiyyah wa Dauruhu fi Iktisab Lughah Arabiyyah lada Tolabah Sanah Thaniah bi Kulliyyah Qiadah wa Idarah. BA thesis. Faculty of Major Languages. Nilai: Islamic Science University of Malaysia.

Muhammad Farid. (2013). Al'aab Lughawiyyah wa Dauruha fi Raf Mustawa Tolabah li Iktisab Tharwah Lughahwiyyah Arabiyyah. BA thesis. Faculty of Major Languages. Nilai: Islamic Science University of Malaysia.

Muhammah Faris. (2012). Istiratijiyyah Taalumi Mufradaat Lughah Arabiyyah lada Tolabah Kulliyyah Lughaat Raisah bi Jamiah Ulum Islamiyyah Maliziyyah. BA thesis. Faculty of Major Languages. Nilai: Islamic Science University of Malaysia.

Nadwah Ibrahim. (2011). Istikhdam Istiratijiyat Ta'allum lada Jamiciyin Natiqin bi Ghayr Lughah Arabiyah. Majallah Dirasat Lughawiyah wa Adabiyah. 2 p. 135-145.

Naimah, A., \& Aini, A. ( Cartographer). (2005). Kajian tentang persepsi pelajar UiTM terhadap kepentingan bahasa ketiga di UiTM.

Nasimah Hj. Abdullah. (2006). Permasalahan dalam Pembelajaran bagi Pelajar Diploma Pengajian Islam (Bahasa Arab) di KUIS dan Cara Mengatasinya. Prosiding Wacana Pengajian Islam, Siri 5.

Nasimah Mu'ti. (2013). Daur Barnamij Taqwiyyah Lughawiyyah fi Raf'I Mustawa Talabah Lughawiyyah fi USIM. BA thesis. Faculty of Major Languages. Nilai: Islamic Science University of Malaysia.

Nur Afifah Muhamad. (2013). Ta'sir Lu'bah Lughawiyyah fi Ta'lim Lughah Arabiyyah li Taqiah Mahaarat Luhawiyah lada Tullab Thanah Thaniah fi USIM. B A thesis. Faculty of Major Languages. Nilai: Islamic Science University of Malaysia.

Nur Aisar Nordin. (2013). Istiratijiah Ta'allum Maharah Kitabah bi Lughah Arabiah li Ghairi Natiqinabiha: Talabah Dilom Tahfiz Quran fi ITQAN. B A thesis. Faculty of Major Languages. Nilai: Islamic Science University of Malaysia.

Nur Amirah Ismail. (2011). Istiratijiyah Tanmiyah Muhadathah bi al-Lughah Arabiyah lada Talabah Sanah Ula fi Jamiah Ulum Islamiyah Maliziyah li al-Ami al-Dirasi 2010/2011. BA thesis. Faculty of Major Languages. Nilai: Islamic Science University of Malaysia.

Nur Azrin Muhamad Radzi. (2013). Istikhdam Istiratijiaat li Tanmiah Maharah Muhadhah bi Lughah Arabiah lada Talabah Kuliah Dirasaat Lughah Raisah. BA thesis. Faculty of Major Languages. Nilai: Islamic Science University of Malaysia.

Nur Farhana Azizi. (2012). Daur Masrahiyyah Tamthiliyyah Arabiyyah fi Taalum Lughah Arabiyyah lada Tolabah Sanah Rabiah fi Kulliyyah Lughaat Raisah bi Jamiah Ulum Islamiyyah Maliziyyah. BA thesis. Faculty of Major Languages. Nilai: Islamic Science University of Malaysia.

Nur Fazila Ismail. (2013). Tariqah Ta'allumi Lughah Arabiyyah bi Wasitoh Hifzi Kalimaat lada Talamiz Marhalah Thanawiyyah. BA thesis. Faculty of Major Languages. Nilai: Islamic Science University of Malaysia.

Nur Hanim Shazana. (2013). Fa'aliyatul Qiraah fi Tarjamah lada Tolabah Sanah Rabiah Takhasus Lughah Arabiyyah bi Kulliyyah Dirasaat Lughah Raisah fi Jamiah Ulum Islamiyyah Maliziyyah. BA thesis. Faculty of Major Languages. Nilai: Islamic Science University of Malaysia. 
Nur Hashimah Hashim. (2012). Asar Qiraah Sahifah Arabiyyah ala Taallumi Lughah Arabiyyah lada Tolabah Sanah Thalithah fi Jamiah Ulum Islamiyyah Maliziyyah. BA thesis. Faculty of Major Languages. Nilai: Islamic Science University of Malaysia.

Nur Khadijah Abu Bakar. (2012) Turuq Taallumi Muhadathah lada Mutanadzirin bi Jamiah Ulum Islamiyyah Maliziyyah. BA thesis. Faculty of Major Languages. Nilai: Islamic Science University of Malaysia.

Nur Najwa Jamaludin. (2013). Aarau Talabah Thanah Thaniah bi Kuliah Dirasaat Lughah Raisahan Ta'sir Musyarakah Anshitoh Usbu'u Arabiah fi Kitabah wa Muhadathah fi USIM. BA thesis. Faculty of Major Languages. Nilai: Islamic Science University of Malaysia.

Nur Syaifura. (2011). Iktisab Maharah al-Muhadathah lada al-Darisin fi al-Masaq al-Thanawi al-Thalith fi Madrasah Sultan Zaynal alAbidin Thanawiyah Diniyah Aliyah bi Teranjanu (SMAASZA). BA thesis. Faculty of Major Languages. Nilai: Islamic Science University of Malaysia.

Nur Wahdah Asma'. (2011). Qiraatul Majallaat Arabiyyah lada Tullab Sanah Thalithah fi Qism Lughaha Arabiyyah bi Jamiah Ulum Islamiyyah Maliziyyah. BA thesis. Faculty of Major Languages. Nilai: Islamic Science University of Malaysia.

Nurazan M. Rouyan. (2004). Strategi Pembelajaran Bahasa dalam Pembelajaran Bahasa Arab: Kajian di KUSZA. MA dissertation. Banggi: Universiti Kebangsaan Malaysia.

Nurhamimi Zainul Abidin \& Muhamad Fiham Muhammad Ghalib. (2012). Istiratijiyat Tullab Ghayr al-Mutakhassisin fi Lughah Arabiyah fi Tacallum Maharat al-Kitabah Abra BarnamijWiki. Journal of Islamic and Arabic Education. 4 (1). P. 31-44.

Oxford, R.L. (1990). Language Learning Strategies: What Every Teacher Should Know. New York: Newbury House Publishers.

Rim Adil al Turk. (2011). Iktisab Maharah Muhadathah li al-Natiqin bi Ghayr al-Arabiyah bi Istiratijiyah Lubiyah: Tamthil Adwar Namuzajan. Prosiding Seminar Antarabangsa Pengajaran Bahasa Arab 2011.

Rohaizaf. (2013). Istikhdam Tariqah Mubasyirah fi Ta'lim Maharat Kalam li Tullab Mubtadiin min Natiqinabiha ka Lughah Thaniah fi Markaz Dirasaat Asasiah bi UIA. Ph.D thesis, Faculty of Major Languages. Nilai: Islamic Science University of Malaysia.

Rohana Nawi. (2012). Istikhdam Maajim Atabiyyah lada Tolabah Jamiah Ulum Islamiyyah Maliziyyah. BA thesis. Faculty of Major Languages. Nilai: Islamic Science University of Malaysia.

Rosni Samah, Mohd Fauzi Abdul Hamid, Shaferul Hafes Sha'ari and Amizan Helmi Mohamad, (2013), Aktiviti Pengajaran Kemahiran Bertutur Bahasa Arab Dalam Kalangan Jurulatih Debat, GEMA Online® Journal of Language Studies. Vol. 13(2), 99-115.

Rosni Samah. (2012). Pembinaan Ayat Bahasa Arab dalam Kalangan Lepasan Sekolah Menengah Agama. GEMA Online® Journal of Language Studies. Vol. 12(2), 555-569.

Rosni Samah. (2014b). Using SILL's Strategies among Student in Learning Arabic Language in Malaysia. Wulfenia Journal. Vol 21 , No. 1. 26-34.

Rosni Samah. (2014a). Suggested Strategies for Non Arabic Speakers in Learning Arabic Language. pensee Journal. Vol 76 , No. 1. 232-239.

Shaferol. (2013). Istikhdam Tariqah Muhakaat fi Iktisab Mufradat Sahafah lada Tulab Kuliah Lughaat Raisah bi Jamiah Ulum Islamiah Maliziah. MA thesis. Nilai: Islamic Science University of Malaysia.

Shahidah Sobri. (2012) Thaddiyaat allati Tuwajihu Tullab Malizina fi Mumarasah Maharah Kitabah. BA thesis. Faculty of Major Languages. Nilai: Islamic Science University of Malaysia.

Syakirah Mohd Razman. (2004). Penggunaan Kamus dalam Pembelajaran BAK: Satu Tinjauan di Kalangan Pelajar Tingkatan Tiga di Empat Buah SMKA. Kertas Projek Sarjana. Universiti Kebangsaan Malaysia.

Siti Asiah Muhamad. (2013). Ta'lim Lughah Arabiah min Khilal Mushahadah Aflam Arabiah: Dirasah Midaniah wa Tahliliah Talabah Sanah Thalithah bi Kuliah Dirasaat Raisah fi USIM. BA thesis. Faculty of Major Languages. Nilai: Islamic Science University of Malaysia.

Siti Nurul Huda. (2013). Asar Ta'allumi Lughah Arabiyyah li Aghrad Sihhiyyah fi Iktisab Mostolahah Sihhiyyah lada Tolabah Lughah Arabiyyah fi USIM. BA thesis. Faculty of Major Languages. Nilai: Islamic Science University of Malaysia.

Sueraya Che Haron (2010). Understanding Arabic-Speaking Skill Learning Strategies among Selected Malay Learners: A Case-Study At The International Islamic University Malaysia (IIUM), Contemporary Issues in Education Research; Aug 2010; ProQuest Education Journals.

Tarmizi Ahmad. (1997). Ta'lim Maharat Kalam wa Ta'allumuha: Dirasah fi Madrasah Thanawiah Wataniah Diniah. MA thesis, Kuala Lumpur: Malaya University.

Tinggari, Saleh Mahjub. (2011). Istiratijiyat Taallum Maharah al-Kalam lada Darisin Maliziyin. Majallah Dirasat Lughawiyah wa Adabiyah. Vol. 2(1), 51-74.

Wan Nur Zadilah. (2012). Maharah Kitabah Arabiyyah li Tolabah Sanah Thalithah fi Kulliyyah Lughaat Raisah bi Jamiah Ulum Islamiyyah Maliziyyah. BA thesis. Faculty of Major Languages. Nilai: Islamic Science University of Malaysia.

Yasir Ismail dan Rahmah Osman. (2011). Munazarah Wasilah li al-Taayush bayna Afrad wa Atraf Mutabayinah fi Mujtama. Majallah Dirasat Lughawiyah wa Adabiyah. 2 (bil. Khas). 282-301.

Yayan Nurbayan. (2011). Using the Imitating Modul Techniques on Insya' Teaching for Improving the Student's Writing Ability in Thesis. International Journal for Educational Studies. 4 (1) p. 99-106. 